\title{
Contraceptive practices and awareness: a survey among nursing staff at a tertiary care hospital
}

\author{
Snigdha Kumari, Mansi Dhingra*, Syed Nawaz Ahmed
}

\begin{abstract}
Department of Obstetrics and Gynecology, ESI Post Graduate Institute of Medical Sciences and Research, Basaidarapur, New Delhi, India
\end{abstract}

Received: 17 September 2019

Accepted: 06 November 2019

\author{
*Correspondence: \\ Dr. Mansi Dhingra, \\ E-mail: drmansidhingra@gmail.com
}

Copyright: (c) the author(s), publisher and licensee Medip Academy. This is an open-access article distributed under the terms of the Creative Commons Attribution Non-Commercial License, which permits unrestricted non-commercial use, distribution, and reproduction in any medium, provided the original work is properly cited.

\begin{abstract}
Background: India is the second most populous country in the world next to China. Increasing the contraceptive awareness and practice and proper implementation of family planning services are the major tool for improving the health of the population along with stabilizing it. Knowledge and contraceptive practice in the Nursing personnel can positively or negatively influence the population coming in contact with them. Objective of this study was to investigate the knowledge and practice of contraceptive methods among the nursing staff at a tertiary care set up.

Methods: Tertiary care set up, cross sectional study. This was a cross sectional study conducted over a period of three months. Fifty staff nurses under the age of 49 years were interviewed through a pre-designed questionnaire regarding knowledge and use of contraceptive methods.

Results: Contraception was practiced in 88 percent of the staff nurses. Barrier method of contraception was the most commonly used form of contraception. Permanent method of contraception was opted in 14 percent of cases. Fiftyseven percent of the females were aware of emergency contraception. Twenty-eight percent of females had used emergency contraception in the past.

Conclusions: A high percentage of nursing staff was practicing some form of contraception; however, the use of permanent methods and hormonal methods remains low. Only half of study population was aware of post coital methods of contraception with only 28 percent having used it in the past.
\end{abstract}

Keywords: Abortion, Awareness, Contraception, Emergency contraception, Staff nurses, Sterilization

\section{INTRODUCTION}

India is the second most populous country in the world next to China. If the current trend of increase in population continues, by 2045 India may become the leading country in the world overtaking China in terms of population. $^{1}$

Increasing the contraceptive awareness and practice and proper implementation of family planning services are the major tool for improving the health of the population along with stabilizing it. Knowledge and attitude of Nursing personnel who are both service providers and health educators to the community can influence the contraceptive behaviour of the people exposed to them. Lack of awareness, misconceptions and negative attitude towards contraception in nursing personnel can both act as a barrier for their personal use and also prevent them from promoting contraception methods to the beneficiaries. In this study we have surveyed 50 nursing staff working at tertiary care hospital, regarding their knowledge and use of various contraceptive methods. 


\section{METHODS}

This was a cross sectional study conducted over a period of three months (January 2018 to March 2018) at a tertiary care set up wherein 50 staff nurses were interviewed through a preformed questionnaire after taking informed consent. The inclusion criteria were all staff nurses under the age of 49 years. Subjects not consenting for the study were excluded from the study. The questionnaire included details such as the age of the person, job and qualification of husband, type of family, number of living issues, awareness of various methods of contraception, contraceptive usage and the use of emergency contraception.

Awareness of emergency contraception was assessed by asking two questions:

- If a woman had unprotected intercourse, is there anything she can do within three days to prevent pregnancy and

- Awareness of methods of post-coital contraception.

\section{Statistical analysis}

Descriptive statistics was analyzed with SPSS version 17.0 software. Continuous variables are presented as mean \pm SD. Categorical variables are expressed as frequencies and percentages. The Pearson's chi-square test or the chi-square test of association was used to determine if there is a relationship between two categorical variables. $\mathrm{P}<0.05$ was considered statistically significant.

\section{RESULTS}

Table 1: Age distribution.

\begin{tabular}{|lll|}
\hline Age groups & Frequency & $\%$ \\
\hline $25-29$ years & 8 & $16.0 \%$ \\
\hline $30-34$ years & 21 & $42.0 \%$ \\
\hline $35-39$ years & 8 & $16.0 \%$ \\
\hline $40-44$ years & 6 & $12.0 \%$ \\
\hline $45-49$ years & 7 & $14.0 \%$ \\
\hline Total & $\mathbf{5 0}$ & $\mathbf{1 0 0 \%}$ \\
\hline Mean \pm SD & $35.38 \pm 6.14$ & \\
\hline Min-Max & $27-49$ & \\
\hline
\end{tabular}

A total 50 married women were included in this study. The demographic characteristics of the women included in the study have been depicted in the tables below (Table 1 and Table 2). Majority of women were in the age group of 30-34 years. The most commonly used methods in the age groups of 25-29 years and 30-34 years were natural and barrier methods of contraception. With advancing age, the use of intrauterine devices and permanent methods (sterilization) increased. Seventy-four percent of women were Hindu by religion, 18 percent were Christian by religion. Husbands of all the subjects were literate. Majority of women had nuclear families (64\%). The deciding member for the use of a particular method were both husband and wife in 62 percent of cases, in eight percent it was the husband, in ten percent it was woman herself and in ten percent of the cases it was the doctor. ten percent of women had two live issues. Nine women had undergone induced abortions. Three out of these had history of induced abortion twice.

Table 2: Demographical distribution.

\begin{tabular}{|lll|}
\hline \multicolumn{2}{|l|}{ Number } & Percentage \\
\hline Religion & 37 & 74 \\
\hline Hindu & 1 & 2 \\
\hline Muslim & 3 & 6 \\
\hline Sikh & 9 & 18 \\
\hline Christian & & \\
\hline Husbands education & 07 & 14 \\
\hline 12 & & \\
\hline Graduation & 33 & 66 \\
\hline Postgraduation & 10 & 20 \\
\hline Deciding member for the use of a particular method \\
\hline Couple together & 31 & 62 \\
\hline Self & 10 & 20 \\
\hline Husband & 4 & 8 \\
\hline Doctor & 5 & 10 \\
\hline Type of family & & \\
\hline Joint & 18 & 36 \\
\hline Nuclear & 32 & 64 \\
\hline No of live issues & & \\
\hline 0 & 05 & 10 \\
\hline 1 & 19 & 38 \\
\hline 2 & 25 & 50 \\
\hline 3 & 1 & 2 \\
\hline & & \\
\hline & & \\
\hline
\end{tabular}

Distribution by religion, husband's education, deciding member for the use of a particular method, type of family, number of live issues, history of induced abortions.

Table 3: Awareness and usage of various contraceptive methods.

\begin{tabular}{|lll|}
\hline A wareness & Frequency & $\%$ \\
\hline Safe period & 48 & $96.0 \%$ \\
\hline Withdrawal method & 50 & $100.0 \%$ \\
\hline Barrier method & 50 & $100.0 \%$ \\
\hline Oral contraceptive pills & 50 & $100.0 \%$ \\
\hline Copper intrauterine devices & 50 & $100.0 \%$ \\
\hline Depot Provera & 6 & $12.0 \%$ \\
\hline Permanent sterilization & 50 & $100.0 \%$ \\
\hline
\end{tabular}

Table 3 depicts the awareness of various contraceptive methods in the study population. Most of the staff nurses were aware of most of the methods of contraception except depot Provera, the awareness of which was particularly low and inaccurate. Majority of information 
was gathered through their study curriculum, colleagues and health professionals.

The awareness about most of the methods of contraception was similar in all the age groups. The younger age groups were more aware of depot Provera as a mode of contraception; however, this wasn't statistically significant (Table 4).
Table 5, 6, 7 depicts the awareness of various methods of contraception depending on educational status of the husbands, type of family and religious background of the woman respectively. The awareness about depot Provera was significantly higher in women whose husbands were graduates or postgraduates. Women belonging to various religious backgrounds and family types were equally aware of the various methods of contraception.

Table 4: Awareness of methods of contraception in various age groups $(\mathrm{p}<0.05)$.

\begin{tabular}{|c|c|c|c|c|c|c|c|c|c|}
\hline \multicolumn{3}{|c|}{ Age groups } & $\begin{array}{l}25-29 \\
\text { vears }\end{array}$ & $\begin{array}{l}30-34 \\
\text { years }\end{array}$ & $\begin{array}{l}35-39 \\
\text { years }\end{array}$ & $\begin{array}{l}40-44 \\
\text { years }\end{array}$ & $\begin{array}{l}45-49 \\
\text { years }\end{array}$ & Total & \multirow{2}{*}{$\begin{array}{l}\mathrm{p} \\
\text { value }\end{array}$} \\
\hline \multicolumn{3}{|c|}{ Total cases } & 8 & 21 & 8 & 6 & 7 & 50 & \\
\hline \multirow{4}{*}{$\begin{array}{l}\mathbf{A} \\
\mathbf{w} \\
\mathbf{a} \\
\mathbf{r}\end{array}$} & Safe period & $\mathrm{n}(\%)$ & $8(100 \%)$ & $20(95.2 \%)$ & $8(100 \%)$ & $5(83.3 \%)$ & $7(100 \%)$ & $48(96.0 \%)$ & 0.478 \\
\hline & Withdrawal & $\mathrm{n}(\%)$ & $8(100 \%)$ & $21(100 \%)$ & $8(100 \%)$ & $6(100 \%)$ & $7(100 \%)$ & $50(100 \%)$ & - \\
\hline & Barrier & $\mathrm{n}(\%)$ & $8(100 \%)$ & $21(100 \%)$ & $8(100 \%)$ & $6(100 \%)$ & $7(100 \%)$ & $50(100 \%)$ & - \\
\hline & $\begin{array}{l}\text { Oral contraceptive } \\
\text { pills }\end{array}$ & $\mathrm{n}(\%)$ & $8(100 \%)$ & $21(100 \%)$ & $8(100 \%)$ & $6(100 \%)$ & $7(100 \%)$ & $50(100 \%)$ & - \\
\hline \multirow{3}{*}{$\begin{array}{l}\mathbf{e} \\
\mathbf{n} \\
\mathbf{e} \\
\mathbf{S} \\
\mathbf{S}\end{array}$} & $\begin{array}{l}\text { Copper intrauterine } \\
\text { devices }\end{array}$ & $\mathrm{n}(\%)$ & $8(100 \%)$ & $21(100 \%)$ & $8(100 \%)$ & $6(100 \%)$ & $7(100 \%)$ & $50(100 \%)$ & - \\
\hline & Depot Provera & n $(\%)$ & $4(50.0 \%)$ & $16(76.2 \%)$ & $6(75.0 \%)$ & $3(50.0 \%)$ & $4(57.1 \%)$ & $33(66.0 \%)$ & 0.541 \\
\hline & $\begin{array}{l}\text { Permanent } \\
\text { sterilization }\end{array}$ & $\mathrm{n}(\%)$ & $8(100 \%)$ & $21(100 \%)$ & $8(100 \%)$ & $6(100 \%)$ & $7(100 \%)$ & $50(100 \%)$ & - \\
\hline
\end{tabular}

Table 5: Awareness of contraceptive methods depending on husband's educational status $(p<0.05)$.

\begin{tabular}{|llllllll|}
\hline Husband occupation & & $1^{\text {th }}$ pass & Graduate & Postgraduate & Total & p \\
Total cases & & & $\mathbf{7}$ & $\mathbf{3 3}$ & $\mathbf{1 0}$ & $\mathbf{5 0}$ & value \\
\hline & Safe period & $\mathrm{n}(\%)$ & $7(100 \%)$ & $31(93.9 \%)$ & $10(100 \%)$ & $48(96.0 \%)$ & 0.585 \\
\cline { 2 - 7 } & Withdrawal & $\mathrm{n}(\%)$ & $7(100 \%)$ & $33(100 \%)$ & $10(100 \%)$ & $50(100 \%)$ & - \\
\cline { 2 - 7 } & Barrier & $\mathrm{n}(\%)$ & $7(100 \%)$ & $33(100 \%)$ & $10(100 \%)$ & $50(100 \%)$ & - \\
\cline { 2 - 7 } Awareness & Oral contraceptive pills & $\mathrm{n}(\%)$ & $7(100 \%)$ & $33(100 \%)$ & $10(100 \%)$ & $50(100 \%)$ & - \\
\cline { 2 - 7 } & Copper intrauterine devices & $\mathrm{n}(\%)$ & $7(100 \%)$ & $33(100 \%)$ & $10(100 \%)$ & $50(100 \%)$ & - \\
\cline { 2 - 7 } & Depot Provera & $\mathrm{n}(\%)$ & $4(57.1 \%)$ & $19(57.6 \%)$ & $10(100 \%)$ & $33(66.0 \%)$ & 0.040 \\
\cline { 2 - 7 } & Permanent sterilization & $\mathrm{n}(\%)$ & $7(100 \%)$ & $33(100 \%)$ & $10(100 \%)$ & $50(100 \%)$ & - \\
\hline
\end{tabular}

Table 6: Awareness of contraceptive methods depending on type of family.

\begin{tabular}{|c|c|c|c|c|c|c|}
\hline \multicolumn{3}{|c|}{ Type of family } & Joint & Nuclear & Total & \multirow{2}{*}{$\begin{array}{l}\text { p } \\
\text { value }\end{array}$} \\
\hline Total cases & & & 18 & 32 & 50 & \\
\hline \multirow{7}{*}{ Awareness } & Safe period & $\mathrm{n}(\%)$ & $17(94.4 \%)$ & $31(96.9 \%)$ & $48(96.0 \%)$ & 1.000 \\
\hline & Withdrawal & $\mathrm{n}(\%)$ & $18(100 \%)$ & $32(100 \%)$ & $50(100 \%)$ & - \\
\hline & Barrier & $\mathrm{n}(\%)$ & $18(100 \%)$ & $32(100 \%)$ & $50(100 \%)$ & - \\
\hline & Oral contraceptive pills & $\mathrm{n}(\%)$ & $18(100 \%)$ & $32(100 \%)$ & $50(100 \%)$ & - \\
\hline & Copper intrauterine devices & $\mathrm{n}(\%)$ & $18(100 \%)$ & $32(100 \%)$ & $50(100 \%)$ & - \\
\hline & Depot Provera & $\mathrm{n}(\%)$ & $12(66.7 \%)$ & $21(65.6 \%)$ & $33(66.0 \%)$ & 0.941 \\
\hline & Permanent sterilization & $\mathrm{n}(\%)$ & $18(100 \%)$ & $32(100 \%)$ & $50(100 \%)$ & - \\
\hline
\end{tabular}

Eighty-eight percent of women were using some form of contraception, barrier method being the most commonly used method (34\%) followed by natural methods and intrauterine devices. The use of OCPs was considerably low. Fourteen percent of women had undergone permanent sterilization (Table 8 ). Table 9 depicts the age- wise distribution of contraceptive usage. The use of permanent sterilization increases with age and this association was statistically significant.

Table 10 below shows the usage of emergency contraception (mainly Tab levonorgestrel $1.5 \mathrm{mg}$ taken 
within 72 hours of unprotected intercourse). Forty percent of the females were aware of emergency contraception. Only 28 percent had used them in the past.
Out of the six nurses not using contraception, four were planning a second pregnancy. One of the non-user's husband stayed abroad and one was afraid of the side effects (Table 11).

Table 7: Awareness of contraceptive methods depending on religious background.

\begin{tabular}{|c|c|c|c|c|c|c|c|c|}
\hline \multicolumn{3}{|c|}{ Religion } & Christian & Hindu & Muslim & Sikh & Total & p \\
\hline \multicolumn{3}{|c|}{ Total cases } & 9 & 37 & 1 & 3 & 50 & value \\
\hline \multirow{3}{*}{$\begin{array}{l}\mathbf{A} \\
\mathbf{w}\end{array}$} & Safe period & $\mathrm{n}(\%)$ & $9(100 \%)$ & $35(94.6 \%)$ & $1(100 \%)$ & $3(100 \%)$ & $48(96.0 \%)$ & 0.866 \\
\hline & Withdrawal & $\mathrm{n}(\%)$ & $9(100 \%)$ & $37(100 \%)$ & $1(100 \%)$ & $3(100 \%)$ & $50(100 \%)$ & - \\
\hline & Barrier & $\mathrm{n}(\%)$ & $9(100 \%)$ & $37(100 \%)$ & $1(100 \%)$ & $3(100 \%)$ & $50(100 \%)$ & - \\
\hline \multirow{2}{*}{$\begin{array}{l}\mathbf{r} \\
\mathrm{e}\end{array}$} & Oral contraceptive pills & $\mathrm{n}(\%)$ & $9(100 \%)$ & $37(100 \%)$ & $1(100 \%)$ & $3(100 \%)$ & $50(100 \%)$ & - \\
\hline & Copper intrauterine device & $\mathrm{n}(\%)$ & $9(100 \%)$ & $37(100 \%)$ & $1(100 \%)$ & $3(100 \%)$ & $50(100 \%)$ & - \\
\hline \multirow{2}{*}{$\begin{array}{l}\text { n } \\
\text { e } \\
\text { ss }\end{array}$} & Depot Provera & $\mathrm{n}(\%)$ & $5(55.6 \%)$ & $26(70.3 \%)$ & $1(100 \%)$ & $1(33.3 \%)$ & $33(66.0 \%)$ & 0.444 \\
\hline & Permanent sterilization & $\mathrm{n}(\%)$ & $9(100 \%)$ & $37(100 \%)$ & $1(100 \%)$ & $3(100 \%)$ & $50(100 \%)$ & - \\
\hline
\end{tabular}

Table 8: Frequency of usage of various contraceptive methods.

\begin{tabular}{|lll|}
\hline Usage & Frequency & $\%$ \\
\hline Safe period & 11 & $22.0 \%$ \\
\hline Withdrawal method & 7 & $14.0 \%$ \\
\hline Barrier method & 17 & $34.0 \%$ \\
\hline Oral contraceptive pills & 4 & $8.0 \%$ \\
\hline Copper intrauterine devices & 10 & $20.0 \%$ \\
\hline Depot Provera & 0 & $0.0 \%$ \\
\hline Permanent sterilization & 7 & $14.0 \%$ \\
\hline None & 6 & $12.0 \%$ \\
\hline
\end{tabular}

*(total does not add up to a $100 \%$ as more than one form of contraception was used by many staff nurses).

Table 9: Age-wise distribution of usage of various contraceptive methods $(p<0.05)$.

\begin{tabular}{|c|c|c|c|c|c|c|c|c|c|}
\hline \multicolumn{3}{|c|}{ Age groups } & $\begin{array}{l}25-29 \\
\text { vears }\end{array}$ & $\begin{array}{l}30-34 \\
\text { vears }\end{array}$ & $\begin{array}{l}35-39 \\
\text { vears }\end{array}$ & $\begin{array}{l}40-44 \\
\text { vears }\end{array}$ & $\begin{array}{l}45-49 \\
\text { vears }\end{array}$ & Total & \multirow{2}{*}{$\begin{array}{l}\mathrm{p} \\
\text { value }\end{array}$} \\
\hline Tot: & l cases & & 8 & 21 & 8 & 6 & 7 & 50 & \\
\hline \multirow{7}{*}{ 总 } & Safe period & $\mathrm{n}(\%)$ & $2(25.0 \%)$ & $5(23.8 \%)$ & $3(37.5 \%)$ & $0(0.0 \%)$ & $1(14.3 \%)$ & $11(22.0 \%)$ & 0.535 \\
\hline & $\begin{array}{l}\text { Withdrawal } \\
\text { method }\end{array}$ & $\mathrm{n}(\%)$ & $1(12.5 \%)$ & $2(9.5 \%)$ & $3(37.5 \%)$ & $0(0.0 \%)$ & $1(14.3 \%)$ & $7(14.0 \%)$ & 0.286 \\
\hline & Barrier method & $\mathrm{n}(\%)$ & $2(25.0 \%)$ & $9(42.9 \%)$ & $2(25.0 \%)$ & $3(50.0 \%)$ & $1(14.3 \%)$ & $17(34.0 \%)$ & 0.524 \\
\hline & $\begin{array}{l}\text { Oral } \\
\text { contraceptive } \\
\text { pills }\end{array}$ & $\mathrm{n}(\%)$ & $2(25.0 \%)$ & $0(0.0 \%)$ & $2(25.0 \%)$ & $0(0.0 \%)$ & $0(0.0 \%)$ & $4(8.0 \%)$ & 0.055 \\
\hline & $\begin{array}{l}\text { Copper } \\
\text { intrauterine } \\
\text { device }\end{array}$ & $\mathrm{n}(\%)$ & $3(37.5 \%)$ & $2(9.5 \%)$ & $2(25.0 \%)$ & $2(33.3 \%)$ & $1(14.3 \%)$ & $4(8.0 \%)$ & 0.419 \\
\hline & $\begin{array}{l}\text { Permanent } \\
\text { sterilization }\end{array}$ & $\mathrm{n}(\%)$ & $0(0.0 \%)$ & $1(4.8 \%)$ & $1(12.5 \%)$ & $0(0.0 \%)$ & $5(71.4 \%)$ & $7(14.0 \%)$ & $<0.001$ \\
\hline & None & $\mathrm{n}(\%)$ & $0(0.0 \%)$ & $5(23.8 \%)$ & $0(0.0 \%)$ & $1(16.7 \%)$ & $0(0.0 \%)$ & $6(12.0 \%)$ & 0.197 \\
\hline
\end{tabular}

Six women opted for only natural methods of contraception (safe period and withdrawal) in the light of high failure rate for the fear of side effects associated with other methods.

\section{DISCUSSION}

Family planning is defined by WHO as, "a way of thinking and living that is adopted voluntarily, upon the basis of knowledge, attitudes and responsible decisions 
by individuals and couples, in order to promote the health and welfare of family groups and thus contribute effectively to the social development of a country".

Table 10: Usage of emergency contraception (mainly levonorgestrel).

\begin{tabular}{|lll|}
\hline Emergency contraception & Frequency & $\%$ \\
\hline No & 36 & $72.0 \%$ \\
\hline Once & 5 & $10.0 \%$ \\
\hline Twice & 6 & $12.0 \%$ \\
\hline Thrice & 1 & $2.0 \%$ \\
\hline 4 times & 1 & $2.0 \%$ \\
\hline 5 times & 1 & $2.0 \%$ \\
\hline
\end{tabular}

Table 11: Reason for not using contraception.

\begin{tabular}{|lll|}
\hline $\begin{array}{l}\text { Reason for not using } \\
\text { contraception }\end{array}$ & Number & $\begin{array}{l}\text { Percentage } \\
\text { (Total 6) }\end{array}$ \\
\hline Want of child in future & 4 & $66.66 \%$ \\
\hline Fear of side effects & 1 & $16.66 \%$ \\
\hline Husband stays abroad & 1 & $16.66 \%$ \\
\hline
\end{tabular}

The study was conducted using a sample size of fifty staff nurses, who represent the urban educated working class. The contraceptive usage was as high as 88 percent. This is very high in comparison to the total contraceptive usage of 56.3 percent among married women in India as per the national family health survey 20052. Husbands of all the study subjects were educated and considering the fact that in 70 percent of cases using contraception the husband had an important role in deciding the use of a particular method, high contraceptive prevalence may be attributed to the high literacy levels of the population under study.

The level of awareness of contraceptive methods in our study group (except depot Provera) was in the range of 95-100 percent. This is in conjunction with other studies where in literacy levels have a positive impact on contraceptive awareness and usage. Tuladhar $\mathrm{H}$ et al also observed in their study that when women's education was of secondary or higher level, awareness was $100.0 \% .{ }^{3}$ His finding is in accordance with the studies done in Pakistan with $95.0 \%$ awareness in educated women as compared with $73.0 \%$ in illiterate women. ${ }^{4}$

Coming to the type of contraceptive used, permanent method of sterilization was used only in fourteen percent of the cases, rest of the cases using temporary methods. Among these barrier methods was the most commonly used followed by copper containing IUDs and natural methods. This is in accordance with the study by Kanojia et al. that spacing methods were more popular among educated urban population. ${ }^{5}$

Despite the fact that contraceptive usage has increased over a period of time, there exists a KAP-gap i.e. a gap between the knowledge, attitude and practices regarding contraception. ${ }^{6}$ This was very true regarding the usage of hormonal contraceptives and female sterilization. Six women opted for only natural methods of contraception despite knowing the high failure rate for the fear of side effects. The use of OCP s was particularly low in contrast to the western countries where it is the method used most commonly. ${ }^{7}$ Knowledge about mirena and depot Provera as contraceptives was not only low but was also highly inaccurate. The usage of these for contraception was zero percent.

Another incidental finding of this study was that only two percent of subjects had more than two children. This depicts the acceptance of the two-child norm and attitude of the working women to go in for a small family.

Only 40 percent of the study population were aware of emergency contraception (mainly levonorgestrel). This is significantly low in comparison to western countries. A survey in United States showed that $36 \%$ of respondents realized that "anything could be done" to prevent pregnancy after unprotected sex and fifty five percent had heard about emergency contraception. ${ }^{8}$ A Swedish study by Aneblom et al, and a survey in Melbourne Health Clinic showed that awareness about emergency contraception was 83 and $80 \%$, respectively. ${ }^{9,10}$ This was however much higher than what was reported by Tripathi et al, (2.7\% of paramedical workers).

Drawbacks of this study was even though the population studied represents the literate working class but it does not represent all the working strata of society. Also due to lack of consent, hesitation on the part of the subjects, unmarried women could not be adequately interviewed.

\section{CONCLUSION}

To summarize, a high percentage of females in this urban, educated, working-women population used contraception. Spacing methods of contraception were more commonly practiced, among those barrier methods of contraception was the most popular method. Awareness of emergency contraception, injectable contraception and LNG-IUS was low and there is an urgent need to promote it.

Funding: No funding sources Conflict of interest: None declared

Ethical approval: The study was approved by the Institutional Ethics Committee

\section{REFERENCES}

1. National Population Policy 2000, Department of Family Welfare, Ministry of Health and FW, Govt. of India, New Delhi. Available at: http://populationcommission.nic.in/PublicationDetail s/11_983_1.aspx. Accessed on 30 ${ }^{\text {th }}$ May 2015.

2. International Institute for Population Sciences (IIPS) and Macro International. National Family Health 
Survey (NFHS-3), Volume I, 2005-06. Available at: https://dhsprogram.com/pubs/pdf/frind3/frind3-

vollandvol2.pdf. Accessed on $18^{\text {th }}$ September 2019.

3. Tuladhar H, Marahatta R. Awareness and practice of family planning methods in women attending gyne OPD at Nepal medical college teaching hospital. Nepal Med Coll J. 2008;10(3):184-91.

4. Zafar MI, Ford N, Ankomah A. Significance of beliefs and values predicting fertility and contraceptive behaviour in Pakistan. J Biol Soc Sci. 1995;27:301-18.

5. Kanojia JK, Nirbhavane NC, Toddywala VS, Betrabet SS, Patel SB, Datte S, et al. Dynamics of contraceptive practice amongst urban Indian women. Natl Med J India. 1996;9:109-12.

6. Ashok S, John S, Jayanti MT. The KAP-Gap in Nepal: reasons for non-use of contraception among couples with an unmet need for family planning. Asia-Pac Popul J. 2000;6(1):25-38.

7. Johansson ED. Future developments in hormonal contraception. Am J Obstet Gynaecol. 2004;190 Suppl 4:S69-71.
8. Delbanco SF, Mauldon J, Smith MD. Little knowledge and limited practice: Emergency contraceptive pills, the public and the obstetrician. Obstet Gynaecol. 1997;89:1006-11.

9. Aneblom G, Larson M, Odlind V, Tyden T. Knowledge, use and attitude towards emergency contraception pills among Swedish women presenting for induced abortion. $\mathrm{Br} \mathrm{J}$ Obstet Gynaecol. 2002;109:155-60.

10. McDonald G, Amir L. Women's knowledge and attitudes about emergency contraception: a survey Melbourne women's health clinic. Aust N Z J Obstet Gynaecol. 1999;39:460-4.

Cite this article as: Kumari S, Dhingra M, Ahmed SN. Contraceptive practices and awareness: a survey among nursing staff at a tertiary care hospital. Int J Reprod Contracept Obstet Gynecol 2019;8:4751-6. 